\author{
“İ̧, Güç” Endüstri İlişkileri ve İnsan Kaynakları Dergisi \\ Cilt:9 Sayı:1, Ocak 2007, ISSN: 1303-2860 \\ “IŞ, Güç" The Journal of Industrial Relations and Human Resources \\ Vol:9 No:1 January 2007, ISSN: 1303-2860
}

\title{
Strike Ballot In Turkish Labour Law
}

\section{DILEK BAYBORA}

\begin{abstract}
Assistant Professor.Dr., Anadolu University, Economics and Administrative Sciences Faculty, Labour Economics and Industrial Relations Department
\end{abstract}

\section{ÖZET}

Türk iş hukukunda grev oylaması, işçi kuruluşu tarafından alınan grev kararının uygulanıp uygulanmamasında, işçilerin isteklerini, düşüncelerini göstermesini ve kesin sonucun ortaya çıkmasını sağlayan demokratik bir kurumdur. 2822 sayılı Toplu İs Sözleşmesi, Grev ve Lokavt Kanunu'nda yer alan grev oylamasına ilişkin düzenlemeler incelenirken 275 sayılı Toplu İş Sözleşmesi, Grev ve Lokavt Kanunu'ndaki düzenlemelerle karşılaştırma yapılmıştır. Bu şekilde, Türk iş hukukunda grev oylamasına ilişkin düzenlemelerin gelişimi ortaya konduktan sonra grev oylamasına ilişkin mevcut düzenlemelerde karşılaşılan sorunlar ve bu sorunlara ilişkin çözüm önerilerin sunulması amaçlanmaktadır. 2822 sayılı Toplu Iş Sözleşmesi, Grev ve Lokavt Kanunu'nda grev oylamasına ilişkin düzenlemelerde bazı değişiklikler yapmak suretiyle bu uygulamanın daha iyi bir hale gelmesi sağlanabilir. Bununla birlikte, grev oylamasına ilişkin mevcut düzenleme, işçilerin çoğunluğunun isteğine aykırı olarak işçi sendikası tarafından alınan grev kararı karşısında iş̧̧ilere görüşlerini açıklama imkanı sağlayan demokratik bir uygulamadır.

Anahtar Kelimeler: Grev oylaması, Türk iş hukuku, grev, işçi sendikası, toplu iş sözleşmesi. 


\section{ABSTRACT}

Strike ballot in Turkish labour law is a democratic application providing disclosure of workers' desires and opinions and revelation of the final decision about whether to apply the strike decision taken by the workers' organization. While we are examining the arrangements of strike ballot in the Collective Labour Agreement, Strike and Lock-Out Act No. 2822, we will compare with the arrangements of strike ballot in the Collective Labour Agreement, Strike and Lock-Out Act No. 275. In this way, we may state historical developments of strike ballot in Turkish labour law. This papers' aim is that arrangements regarding strike ballot will be examined, and problems of existing arrangements and potential solutions to these problems will be discussed. The application of strike ballot may be improved by means of making some amendments in the Collective Labour Agreement, Strike and Lock-Out Act No. 2822 concerning strike ballot. However, it is a democratic application providing opportunities to workers for expressing their opinions against a strike decision taken by the trade union contrary to the will of the majority of workers.

Key Words: Strike ballot, Turkish labour law, strike, trade union, collective labour agreement.

\section{INTRODUCTION}

Strike and lock-out were prohibited by Labour Act No. 3008 adopted in 1936 in Turkey (Labour Law Act No. 3008 Article 72), and there were some penal provisions (Labour Law Act No. 3008 Article 72 and continuation) against violations of these prohibitions within the Act. As strike and lock-out were prohibited, obligatory conciliation was stipulated in case of collective labour disagreements. Even the parties were unwilling, they were obliged to abide by the decisions of the Conciliation Board. We may state that this period was not good for parties in terms of protecting their own rights.

Strike prohibition was abolished by the 1961 Constitution and the right to strike was entitled a Constitutional basis, and details of the right to strike were left to the act to be issued (1). The Collective Labour Agreement, Strike and Lock-Out Act (CASL Act) No. 275 was adopted in 1963 and the Act included detailed arrangements with regard to strike and lock-out.

Some arrangements regarding the right to strike were also included in the 1982 Constitution (2) as in the 1961 Constitution, and details regarding the exercise of the right to strike were left to the act to be issued. CASL Act No. 2822 (Official Gazette, Date.07.05.1983, 
Issue.18040.

Available

http://www.ilo.org/public/english/region/eurpro/ankara/legislation/act282 2.htm) which was adopted in 1983 covers some detailed arrangements regarding strike and lock-out. Although some amendments have been made at times, CASL Act No. 2822 is still in force.

Strike ballot is an application attaching a democratic quality to strike and preventing the trade union officers to have unconditional will power over the decision to strike by resorting to the opinions of workers about strike by secret voting before strike decision is taken (Tunçomağ, 1988: 500). Strike ballot in Turkish labour law is a democratic application providing disclosure of workers' desires and opinions and revelation of the final decision about whether to apply the strike decision taken by the workers' organization (Erkul, 1974: 189; Çolakoğlu, 1971: 324). Thus, we may briefly define strike ballot as resorting to the will of workers in terms of starting or maintaining a strike (Çifter, 1997: 77). The interim commission report of Turkish Grand National Assembly on CASL Act No. 275 states that "... it is not possible to accept that a great number of workers who do not wish to call a strike are subjected to harm because of a few workers in key positions going on a strike. Otherwise, the exercise of the right to strike shall not conform to democratic principles...." (Sendikalar, 1964: 99-100).

There are various methods applied in countries concerning strike ballot. In some countries workers or trade unions call a strike without resorting to strike ballot. In France, there is no obligation to take a strike ballot before calling a strike and even the majority voting against the strike does not prevent the strike. However, in some countries there is the obligation of a trade union going on a strike to resort to the vote of its workers (Kutal, 1975: 333). In United Kingdom, it is obligatory for the trade union to resort to voting of members registered in establishments within the scope of the strike decision before going on a strike. There is no legal arrangement regarding strike ballot in the United States. In addition, there is no common opinion regarding strike ballot application by trade unions in court decisions. However, it is observed that trade unions resort to strike ballot in practice in an aim to ensure the success of the strike before the decision to call a strike is taken and that they have adopted related provisions in their regulations (Çifter, 1997: 78-79; Ünal, 1993: 20, 32).

It is feasible to resort to strike ballot during the first decision making stage or for determining whether to maintain an ongoing strike or not. There is no legal obligation of trade unions to perform strike ballot 
before the practice of strike in Turkish labour law. However, undoubtedly, there are some legal arrangements in law concerning the practice of strike ballot. Strike ballot is taken if demand arises before the practice of strike.

In this article, first of all we will discuss strike and announcement of strike as strike ballot in Turkish labour law is a practice carried out after the announcement of strike decision in the establishment. Then, arrangements regarding strike ballot will be examined, and problems of existing arrangements and potential solutions to these problems will be discussed.

\section{STRIKE BALLOT IN TURKISH LABOUR LAW}

\subsection{In General}

Provisions regarding strike ballot in Turkish labour law do not bear a statutory characteristic. It states that strike ballot shall be taken if demand arises before the practice of strike. According to CASL Act No. 2822, a strike may not be considered unlawful if it begins without demand for taking a strike ballot (Y. 9. HD. 14.02.1967, 1128/1130; Y. 9. HD. 09.01.1969, 17926/21; Orhaner and Orhaner, 1969: 679-680, 685). However, a strike is unlawful if it begins without voting despite the demand for a strike ballot (Narmanlığlu, 2001: 630; Çolakoğlu, 1971: 325).

The Turkish Labour Party brought a law suit claiming that some articles of CASL Act No. 275 are against the Constitution and the request of the party for the annulment of Article 22 of CASL Act No. 275 was based on grounds that " $\ldots$ in accordance with Paragraph 1 of Article 22, the obligation to take strike ballot in establishments shall cause the employer to put pressure on some workers in the exercise of the right to strike and shall make it difficult to exercise the right. Workers' organization may determine by their own regulations whether this ballot is required or not. The provision stipulating the application of ballot only in the establishments even it is deemed obligatory is against the characteristic of the right"(Çifter, 1997: 86). The Constitutional Court dismissed the law suit on grounds that;

Strike ballot is a precaution stipulated for preventing the labour union to exercise a decision against the opinion of the majority of workers. It is quite clear that this precaution is democratic. Therefore, trade union officers are not given the opportunity to take any action against the will of workers by misconceiving the situation (Decision of 
the Constitutional Court, 19-20.10.1967, 1963-337/1967-31; Official Gazette, Date.02.05.1969, Issue.13188).

We may consider this decision of the Constitutional Court valid in terms of the 1982 Constitution as the arrangement in Article 22 of CASL Act No. 275 shows similarity to the arrangement in Article 35 of CASL Act No. 2822.

Workers are given the opportunity to abort a strike decision taken against their will by strike ballot and on the other hand worker organizations are not set completely free concerning this matter (Erkul, 1974: 189; Çolakoğlu, 1971: 324). Strike ballot also prevents going on a strike against the will of the majority and prevents the majority who are against strike from suffering losses. However, there are some negative opinions concerning strike ballot in Turkish labour law stating that strike ballot is an obstructive tool in that the trade union may take a strike decision following a long process, that the employer may ensure that the strike ballot results in a way he/she wants by sabotaging the ballot by employing new workers as only workers working in that establishment on announcement date of strike may participate in the strike ballot, that strike ballot is taken among trade union members in Western Europe before taking strike decision as it means determining whether to call a strike or not and the arrangement in CASL Act No. 2822 is not in conformity with the law in these respects and it should be excluded from the Act (For additional information about positive and negative opinions concerning strike ballot in Turkish labour law see Ünal, 1993: 64-72).

\subsection{Strike and Announcement of Strike}

According to CASL Act No. 2822 strike is defined as any concerted cessation by workers of their work with the object of halting the activities of a given establishment or of paralysing such activities to a considerable extent, or any abandonment by workers of their work in accordance with a decision taken to that effect by an organisation (Article 25/l). The term lawful strike is defined in CASL Act as well as the term strike. According to this definition lawful strike is any strike called by workers in accordance with CASL Act No. 2822 with the object of safeguarding or improving their economic and social position and working conditions in the event of a dispute arising during negotiations of collective labour agreement (Article 25/II). A strike should be carried out in accordance with the provisions of CASL Act No. 2822 for it to be considered a lawful strike. Announcement of strike is only possible after collective bargaining process is over both according to CASL Act No. 
275 (For additional information about strike and announcement of strike as per CASL Act No. 275 see Oğuzman, 1975; Reisoğlu, 1975; Erkul, 1974; Çolakoğlu, 1971) and CASL Act No. 2822.

According to CASL Act No. 2822, an employers' union shall have power to conclude a collective labour agreement covering all the establishments owned by the employers belonging to the union. Any employer who is not a member shall have power to conclude a collective labour agreement covering the establishment or establishments owned by him (Article 12/II). CASL Act No. 2822 puts forward some requirements for a trade union to be authorised to conclude a collective labour agreement. The trade union representing at least 10 percent of the workers engaged in a given branch of activity (excluding the branch of activity covering agriculture, forestry, hunting and fishing) and more than half of the workers employed in the establishment or each of the establishments to be covered by the collective labour agreement shall have power to conclude a collective labour agreement covering the establishment or the establishments in question. In the case of enterprise collective labour agreements, the establishments shall be considered as one whole unit in the calculation of more than half majority (Article 12/l).

As shown in Figure 1, (Click here to see Figure 1) according to CASL Act, a trade union that considers itself competent to conclude a collective labour agreement shall make application in writing to the Ministry of Labour and Social Security, requesting the ministry to determine that its membership within the branch of activity (excluding the branch of activity covering agriculture, forestry, hunting and fishing) in which the union is constituted represents at least 10 percent of the workers engaged in that branch, and to determine the number of workers employed and the number of members in the establishment or establishments to be covered by the agreement as of the date of such application. Trade union shall give the membership forms in its keeping to the employer within three working days as of the date of its application to the Ministry of Labour and Social Security for determining competence (Article 13/l). An employers' union or an employer not belonging to any such union that considers itself competent to conclude a collective labour agreement shall make application in writing to the Ministry of Labour and Social Security, requesting the ministry to determine the competent trade union (Article 14/I).

If trade union applies to the Ministry of Labour and Social Security for determining competence, where the union has the required majority 
according to the records of the Ministry, the Ministry shall communicate the application, together with the number of workers employed and the number of union members in each establishment concerned, to other trade unions constituted in the same branch of activity and to employers' unions and employers not belonging to such unions who shall be a party to the agreement, within six working days of receiving the application, as indicated in the records of the Ministry at the date of the application. Where it is determined that the trade union does not have the required majority, this information shall be communicated only to the applicant union within the same time limit (Article 13/II). If employers' union or employer applies to the Ministry of Labour and Social Security for determining the competent trade union, the Ministry shall communicate the name and address of the competent trade union, together with the number of workers engaged in that branch of activity and the number of workers employed in each of the establishments concerned and the membership figures of the competent trade union in the branch of activity and in each of the establishments, to other trade unions constituted in the same branch of activity and to the applicant employers' union or to the employer not belonging to any union, within six working days of receiving the application (Article 14/II).

Upon receiving the communication, any workers' or employers' union or an employer not belonging to such a union may lodge an appeal with the court having jurisdiction in labour matters at the locality of the regional directorate where the establishment is registered, within six working days after the receipt of such communication, disputing the competence of either one or both of the parties by indicating the reasons or claiming that they themselves have the required majority. CASL Act sets a limit to those who qualify for lodging an appeal against the communication. According to CASL Act, any labour union which represents less than ten percent of workers within the branch of activity in which the union is constituted may not lodge an appeal against competence (Article 15/I). The aim is to prevent the procedures relating to the determination of competence from taking much longer than necessary. Appeal to court shall suspend the procedure to determine competence until the final ruling (Article 15/III).

According to Article 16/l of CASL Act No. 2822, a certificate of competence shall be issued to the union concerned by the Ministry of Labour and Social Security within six working days after the expiry of the time limit allowed for an appeal if no appeal has been lodged, or within six working days of receiving notice of the decision if the court rejects the appeal. Figure 2 describes (Click here to see Figure 2 ) 
invitation to collective bargaining upon receiving the certificate of competence according to CASL Act. Parties may commence negotiations for the collective labour agreement after invitation to collective bargaining is issued. The certificate of competence shall be void if conditions stipulated in CASL Act concerning invitation to collective bargaining are not satisfied (Article 17). Collective labour agreement shall be concluded on condition that parties agree in collective bargaining process. If parties may not reach an agreement in collective bargaining process, the dispute should be determined as indicated in Figure 3. (Click here to see Figure 3 )

Upon notification of a dispute as shown in Figure 3 the mediation process shall begin. Determination of mediators has been regulated in Article 22 of CASL Act No. 2822. Upon determination of the mediator in accordance with CASL Act, the mediator shall make every effort to make proposals to interested parties (Article 23/II). If parties come to an agreement at the end of the time limit for mediation, then it means that the collective labour agreement shall be concluded (Article 23/III). If the parties fail to come to an agreement at the end of the time limit fixed for mediation, the mediator shall record the dispute in a report and transmit this report to the competent authority (3) together with his proposals to bring about a settlement of the dispute. The competent authority shall transmit a copy of this report to each of the parties (Article 23/IV).

Parties may decide to call a strike and order a lock-out as shown in Figure 4 (Click here to see Figure 4 ) only after receiving this report. A strike decision should have been taken in order to declare a lock-out (For additional information on the legal strike process see Çelik, 2004; Güven and Aydın, 2002; Erkul, 1991; Narmanlıoğlu, 1990; Berksun and Eşmelioğlu, 1989; Tunçomağ, 1988; Sur, 1987). CASL Act No. 275 states that the conciliation process shall begin after the determination of dispute, while CASL Act No. 2822 states that the mediation process shall begin. As a matter of fact, both acts serve for the same purpose. The expressions, the formation of the conciliation board and the selection of the mediator show some differences (For additional information on arrangement in CASL Act No. 275 see Oğuzman, 1975; Erkul, 1974; Çolakoğlu, 1971. For additional information on arrangement in CASL Act No.2822 see Çelik, 2004; Erkul, 1991; Narmanlıoğlu, 1990; Berksun and Eşmelioğlu, 1989; Tunçomağ, 1988; Sur, 1987). According to CASL Act No.2822, the strike decision may be taken at the end of six working days as of the notification of the dispute report issued by the mediator. After that period of time passes, the lawful strike decision may be taken within six working days by the trade 
union being a party to the dispute. The certificate of competence shall be void if no strike decision is taken within this time period or no appeal is made to the High Court of Arbitration concerning prohibition of strikes. The employers' union or the employer not belonging to any union, which is party to the dispute, may take a lock-out decision within six working days as of the date on which the decision of the trade union to call a strike is notified to him (Article 27). According to Article 28 of CASL Act, a decision to call a strike or order a lock-out taken in accordance with the CASL Act shall be submitted to a notary public to be communicated to the other party within six working days as of the date of the decision and one copy of the decision shall be submitted to the competent authority. The decision to call a strike or order a lock-out shall be immediately announced in the establishment or establishments concerned by the receiving party.

\subsection{Strike Ballot}

\subsubsection{The Scope of Strike Ballot}

According to CASL Act No. 2822, strike ballot shall be taken separately for each establishment even if the strike decision is taken for more than one establishment belonging to a single employer or different employers (Çifter, 1997: 89; Oğuzman, 1975: 150; 325; Reisoğlu, 1975: 366; Kutal, 1975: 335; Çolakoğlu, 1971). Enterprise collective labour agreements are regulated in CASL Act apart from establishment collective labour agreements (4). When strike decision is declared at the stage of concluding an enterprise collective labour agreement, the request for a strike ballot shall be made to the highest civil authority in the locality where each establishment of the enterprise is located. After the majority qualifying for strike ballot is attained, the final results of strike ballot are collected at the highest civil authority' office in the locality where the central office of the enterprise is located, and the final result shall be determined there (Article 36/IV). If workers decide not to call a strike in the enterprise as a result of the strike ballot, no strike is called in any establishment, or if strike decision is taken, then a strike may be called in all establishments (Oğuzman, 1987: 199).

No strike ballot may be taken in establishments determined by the Council of Ministers during temporary prohibition of strikes and in activities and establishments where strikes are prohibited (Kocaoğlu, 1986: 10-11). In disputes concerning the activities and the establishments where strikes and lock-outs are prohibited, any party may apply to the High Court of Arbitration within six working days of receipt of the report or after six months have elapsed in the case of 
temporary prohibition of strikes and lock-outs (Article 32). In case of the suspension of a legal strike by the Council of Ministers, no strike ballot request may be made and strike ballots already requested may not be taken. If parties are unable to reach an agreed settlement within the time limit set for suspension or do not resort to private arbitration, the dispute settlement shall be left to the High Court of Arbitration (Article 34).

\subsubsection{Conditions for Strike Ballot}

Some amendments have been made to arrangements in CASL Act No. 275 concerning strike ballot (5) in an effort to solve problems experienced in the application of these arrangements and a similar arrangement has been included in CASL Act No. 2822. There is no statutory provision both in CASL Act No. 275 and CASL Act No. 2822 concerning strike ballot. Strike ballot is not a legal obligation for performing a strike. A strike may be called without resorting to strike ballot and a strike called without a strike ballot may not be claimed to be unlawful (Y. 9. HD. 14.02.1967, 1128/1130; Y. 9. HD. 09.01.1969, 17926/21; Orhaner and Orhaner, 1969: 679-680, 685).

Strike ballot is regulated in Article 35 of CASL Act No. 2822. According to this article,

A strike ballot shall be taken in an establishment if one fourth of the workers employed in that establishment on the date the decision to call a lawful strike is announced request in writing, within six working days after such announcement, that a strike ballot should be taken. The request for a strike ballot shall be made to the highest civil authority in the locality (Article 35/I).

According to CASL Act No. 2822, the following conditions should be fulfilled for performing a strike ballot;

a. The strike decision should be announced in the establishment in accordance with the provision regulated in CASL Act.

b. The request for a strike ballot should be made by one forth of the workers employed in the establishment where a strike is announced.

c. The request for a strike ballot should be made to the highest civil authority in the locality in writing. 
d. The request for a strike ballot should be made within six working days as of the date of announcement of strike in the establishment.

a. There should be a strike decision announced in the establishment and taken by a competent trade union for a strike ballot to be taken (See 2.2.). According to CASL Act No. 275, the organisation authorised to conclude a collective labour agreement is the competent trade union or federation (CASL Act No. 275 Article 7). However, the authorised worker organisation is the trade union which has been issued a certificate of competence according to CASL Act No. 2822. Although the expression "Strike means any concerted cessation by workers... or any abandonment by workers..." is included in article 25 of CASL Act No. 2822, it is not possible for workers to take a concerted lawful strike decision. According to both CASL Act No. 275 and CASL Act No. 2822, those authorised to conclude a collective labour agreement on the side of employers are the employers' union or the employer not belonging to any employers' union. According to both Acts, it is obligatory to complete the collective bargaining process regulated by the Law in order to announce a strike. On condition that the trade union and the employers' union or the employer not belonging to any union come to an agreement in the process of collective bargaining in which both parties mutually express their opinions and make a bargain, a collective labour agreement shall be concluded and no strike shall be called or no lock-out shall be ordered. If the parties may not come to an agreement in the process of collective bargaining, it is not possible to resort to a strike or lock-out immediately. However, the trade union being a party to the dispute may take a strike decision and announce the decision in the establishment after the mediation process begins as regulated in the CASL Act.

b. According to CASL Act No. 2822, one fourth of the workers employed in an establishment where a strike is announced should request a strike ballot for a strike ballot to be taken. It was regulated in CASL Act No. 275 that one third of workers employed in an establishment should request a strike ballot. There is no limitation stating that the request for strike ballot should be made only by workers who are members of the workers' organisation being a party to collective labour dispute either in CASL Act No. 275 or CASL Act No. 2822. As a strike to 
be called in the establishment shall affect all workers, it is required that one fourth of all workers employed in that establishment, whether union members or not, on the date of announcement of strike decision should request the decision to strike (Çelik, 2004: 579; Erkul, 1991: 205; Berksun and Eşmelioğlu, 1989: 544; Tunçomağ, 1988: 500) (6). There was no arrangement in CASL Act No. 275 concerning whether to consider number of workers on the date of strike announcement or on the date of performing the strike ballot in determination of the total number of workers in the establishment. However, it was stated that taking the number of workers on the date of announcement of strike decision as basis shall be more appropriate as some malicious acts are possible after the announcement of strike decision like employers dismissing those workers in favour of the strike or employing new workers which may definitely have effect on the result of the strike ballot (Kutal, 1975: 336). In article 35 of CASL Act No. 2822, missing aspects concerning this matter were compensated by using the expression "...the workers employed in that establishment on the date the decision to call a lawful strike...". The request of a specific ratio of all workers employed in the establishment is meant to be all workers employed except for the employer and the employer's representative (Çifter, 1997: 90; Tunçomağ, 1988: 500; Reisoğlu, 1975: 368; Kutal, 1975: 335; Oğuzman, 1975: 150; Çolakoğlu, 1971: 325) (7). However, if family members are employed in the establishment under labour contract outside the scope of law of domestic relations, it is necessary not to consider these individuals apart from other workers employed in the establishment and to take them into account both in the request for a ballot and majority for a ballot (Narmanlıoğlu, 1990: 202). Persons who are employed on the date of announcement, who are ill, on leave and temporarily appointed shall also be included in the one fourth ratio. However, workers whose labour contracts are terminated on that date shall not be considered within that one fourth ratio (Berksun and Eşmelioğlu, 1989: 543-544; Tunçomağ, 1988: 500-501). The one fourth ratio in enterprise collective labour contracts shall be estimated considering the total number of workers employed in all establishments affiliated to the enterprise (Berksun and Eşmelioğlu, 1989: 544). 
c. The request for a strike ballot should be made to the highest civil authority in the locality in writing. The form of the writing is not clearly stated in the CASL Act. However, requests of workers with signed petitions indicating their names and surnames are under consideration (Erkul, 1991: 206) (8). Workers may make their request for a strike ballot under a single document and under separate documents as well (Çelik, 2004: 578-579). If the request for a strike ballot is made by separate petitions, the petitions shall be gathered and the authority shall evaluate whether the required number is attained. The highest civil authority in the locality is the governors of provinces, governors of districts and heads of sub districts. Head of the sub district is the competent civil authority when the establishment is located within the boundaries of a village (Provincial Administration Law No. 5442; Official Gazette, Date.18.06.1946, Issue.7236).

d. The request for a strike ballot should be made within six working days as of the announcement of the strike decision in the establishment. The period of six working days is for the forfeiture of the right. It is not possible to request a strike ballot at the end of this period (Erkul, 1991: 206; Narmanlıoğlu, 1990: 202; Oğuzman, 1975: 151; Reisoğlu, 1975: 367; Y. 9.HD. 09.01.1969, 17926/21; Ekonomi, İHU). It will be appropriate to consider six working days as of the first day following the date of announcement in estimation of this period of time (Tunçomağ, 1988: 501; Reisoğlu, 1975: 367; Çolakoğlu, 1971: 326 . The day of the announcement and Sundays shall not be included in that six working day estimation Y. 9. HD., 15.12.1966, 12297/11607; Orhaner and Orhaner, 1969: 681-682).

\subsubsection{Taking a Strike Ballot}

A strike ballot shall be taken upon the request of one fourth of workers employed in the establishment after the announcement of strike in that establishment. How to take a strike ballot is regulated by the CASL Act. According to article 35/II of CASL Act No. 2822,

A strike ballot shall be taken within six working days after the request has been made on such date and time outside working hours specified by the highest civil authority under his supervision or that of an official designated by him, on the basis of secret ballot and open returns and classification. 
Within the general systematic of CASL Act No. 2822, time periods have been clearly stated. A strike ballot shall be taken within six working days as of the date of request in accordance with this systematic. A strike ballot shall be taken on the date and time outside working hours specified by the civil authority under his supervision or that of an appointed official, e.g. the Regional Director of Labour or a labour inspector. Lists of workers employed in the establishment shall be prepared and votes shall be taken in return for signatures. The aim is to prevent disruption of works by taking the strike ballot outside working hours, and thus the most appropriate time for ballot should be chosen if a great number of workers are employed in the establishment or workers are working in shifts (Erkul, 1991: 206; Berksun and Eşmelioğlu, 1989: 545). It will be appropriate to announce the date and time of the ballot in the establishment one day before the ballot (Oğuzman, 1975: 152; Erkul, 1974: 188). Although there is no related arrangement in CASL Act No. 2822, one representative of the trade union and one of the employer may present as observers during the strike ballot. It will be appropriate that the report to be prepared is signed by these observers as stated (Çifter, 1997: 91), but there is no requirement concerning this matter. The representatives may only present as observers and they have no right to intervene in the strike ballot. Although there is no arrangement in CASL Act No. 275 concerning the ballot to be performed in the form of secret ballot and open returns and classification, it will be appropriate to act accordingly as stated in the doctrine (Oğuzman, 1975: 151; Erkul, 1974: 188; Çolakoğlu, 1971: 326). This matter is clearly stated in CASL Act No. 2822 thus compensating the missing aspects of CASL Act No. 275.

\subsubsection{Consequences of a Strike Ballot}

It was clearly regulated by CASL Act No. 2822 how to act upon a decision against strike is taken with qualified majority as a result of a strike ballot taken in an establishment. According to article 35/III of CASL Act, if an absolute majority of the workers employed on the date the announcement is made decides against a strike in the establishment, the strike shall not be called. According to this arrangement the absolute majority of workers employed in the establishment on the date of the announcement of strike shall matters instead of the absolute majority of workers participating in the strike ballot, and the strike shall not be called when this majority is attained. In other words, the strike shall not be called if $50 \%+1$ of workers employed in the establishment vote against the strike. There was no arrangement in CASL Act No. 275 concerning whether to look for the absolute 
majority of workers employed in the establishment where the strike ballot is requested, or the absolute majority of workers participating in the strike ballot. It has been stated in the doctrine that if an absolute majority of workers vote against the strike, the strike shall not be called in that establishment no matter how many workers have participated in the strike ballot (Kutal, 1975: 336). CASL Act No. 2822 states that the strike shall not be called in the establishment if an absolute majority of workers employed in that establishment on the date of the announcement of strike vote against the strike, which is quite an appropriate statement. If workers employed in the establishment on the date of announcement of strike quit job before the strike ballot is taken, they may not request a strike ballot or participate in the strike ballot. However, they shall be considered in terms of providing the majority for the request for a strike ballot and the strike ballot itself as being workers employed in the establishment on the date of announcement of strike (Çifter, 1997: 92; Oğuzman, 1987: 200).

The result of the strike ballot shall be recorded in a report, to be prepared in four copies. One copy shall be transmitted to the employer, another to the trade union that decided to call the strike and a third copy to the regional directorate of labour. A fourth copy shall be retained by the highest civil authority in the locality (Article 36/I).

It was stated in CASL Act No. 275 that a strike decision may be applied within the time limit set for appeal against the ballot when a decision is taken in favour of calling a strike in the establishment as a result of the strike ballot (Kutal, 1975: 336). The Supreme Court has taken a decision stating that "... a strike may not necessarily be qualified as unlawful if it has already been called by the trade union within the time limit set for appeal against the strike ballot" (Y. 9. HD., 14.02.1967, 1128/1130; Ekonomi, IHU). There is no arrangement in CASL Act No. 2822 concerning this matter. However, the decision to strike may only be applied after the time period set for appeal is over as the employer also has the right to appeal against the strike ballot (See 2.3.5.) even a decision in favour of a strike is taken as a result of the strike ballot taken in the establishment (Narmanlıoğlu, 1990: 205; Oğuzman, 1975: 153; Reisoğlu, 1975: 371; Çolakoğlu, 1971: 327-328; Ekonomi, İHU). The strike decision shall not be applied within the time period set for appeal against the strike ballot and the strike shall not be called in that establishment before the strike ballot is completed (YHGK. 14.12.1966 9-1119/323; Orhaner and Orhaner, 1969: 682-685). 
There was no arrangement in CASL Act No. 275 concerning how to act if a decision against strike is taken as a result of the strike ballot. It was stated in Circular 12 (No. 1966-1-3/11945 and dated 13.10.1975) of the Ministry of Labour that workers' organization may apply for invitation if the strike ballot results on the contrary; however, it was also stated that the agreement between the parties shall be considered as a valid collective labour agreement (Reisoğlu, 1975: 373). Missing aspects of CASL Act No. 2822 concerning this matter were compensated and two alternatives for the trade union were mentioned in Article 36/III. According to this arrangement;

The certificate of competence shall be void if the trade union being a party to the dispute may not come to an agreement with the other party or does not apply to the High Court of Arbitration within fifteen days as of the final result of the ballot after the strike decision is taken by the workers as a result of the strike ballot.

The trade union being a party to the dispute shall not immediately forfeit its right to conclude a collective labour agreement when an absolute majority of workers employed in the establishment vote for a strike as a result of the strike ballot taken. The trade union may come to an agreement with the other party or apply to the High Court of Arbitration within fifteen days. Otherwise, the certificate of competence shall be void and a new application for certificate of competence shall be required for concluding a collective agreement. The trade union being a party to dispute may sign an agreement which is not that much good for the sake of not forfeiting competence. For this reason, it would be more appropriate to make an arrangement in the CASL Act concerning the immediate forfeiture of competence of the trade union as stated in the doctrine (Çelik, 2004: 579-580). The trade union is allocated a fifteen-day period for reaching an agreement with the other party as it is no doubt that the union shall protect the rights of workers upon a decision against strike is taken as a result of a strike ballot, which is deemed appropriate. However, it is stated that the right to appeal to the High Court of Arbitration is not appropriate on grounds that the mentioned right does not comply with the autonomy of collective labour agreements and it may lead the union not having enough power to execute the strike decision encourage strike ballot and try to obtain what it is unable to get on its own by means of the High Court of Arbitration (Çifter, 1997: 94-95).

There is no clear arrangement in the CASL Act concerning what is supposed to happen if the parties come to an agreement after the trade 
union forfeits its competence. In such a case article 16/II of CASL Act No. 2822 may be referred to. According to this article,

Where a collective labour agreement is concluded without a certificate of competence, any interested party or the Ministry of Labour and Social Security may lodge an appeal within 45 days of the finding of the fact by the ministry to the effect that either one or both of the parties is incompetent and that the agreement should therefore be null and void (9).

With regard to a law suit brought for cancellation of a collective labour agreement signed when the trade union reached an agreement with the other party after forfeiting its competence, the Supreme Court has concluded that the forfeiture of the trade union is not sufficient and it is required to determine whether the union was competent on the date when the collective labour agreement was concluded (Y. 9. HD., 08.04.1992, 356/3031; Çelik, 2004: 541). When the trade union forfeits its competence as a result of a strike ballot, whether the union qualifies for conditions of competence should be considered and if it qualifies, the collective labour agreement to be concluded afterwards should be considered as valid. The collective labour agreement should be cancelled if it is found out that the trade union does not qualify for conditions of competence (Çelik, 2004: 541; Narmanlıoğlu, 2001: 461462).

There is no arrangement in the CASL Act concerning the effects of a decision taken against the strike as a result of a strike ballot on the lockout decision. It is stated that ordering a lock-out is not possible as calling a strike is not possible either (Çelik, 2004: 580; Berksun and Eşmelioğlu, 1989: 547). However, it is also stated that a lock-out decision taken by the employer shall not be affected by a strike ballot and a lock-out may be ordered even when a strike is not called (Reisoğlu, 1975: 372). But ordering a lock-out is not possible if a decision against the strike is taken as a result of the strike ballot. Because the CASL Act provides two alternatives in case of a decision against strike. The trade union may conclude a collective labour agreement with the employer or may apply to the High Court of Arbitration as the decision of the High Court of Arbitration is considered as a collective labour agreement. Otherwise, certificate of competence belonging to the trade union shall be void. The dispute shall be settled when a collective labour agreement is concluded or the High Court of Arbitration takes a decision. The workers shall not be a party to the dispute as the certificate of competence shall be void if the trade union 
may not come to an agreement with the other party or does not apply to the High Court of Arbitration. Lock-out is a defence tool against the strike. When a strike is not called and it is required to reinitiate competence procedures in order to commence the bargaining process for the collective labour agreement, the application of lock-out shall lose its significance which means suspending all workers thus completely halting all activities in the establishment.

When a strike is called as a result of the strike ballot, all obstacles against the application of the strike in the establishment shall be removed. A decision to call a strike may be executed within sixty days following its communication to the other party and on the date notified to the other party six working days beforehand through a notary public (Article 37/I). Where a strike ballot is taken, the sixty-day period shall start on the date the results of the ballot are final (Article 37/III).

\subsubsection{Appeal against a Strike Ballot}

The appeal against a strike ballot has been regulated by CASL Act No. 2822. However, the reasons to appeal have not been stated in the CASL Act. According to Article 36/II of CASL Act, appeal against the ballot shall be lodged with a local court of law having jurisdiction in labour matters within three working days as of the date of ballot. The court shall make a final decision about the appeal within three working days. CASL Act clearly states the time periods within which an appeal against a ballot shall be lodged and within which a final decision shall be taken by the court in accordance with the general systematic of CASL Act No. 2822. The day on which the ballot is taken shall not be taken into consideration in estimation of this three-working day period in terms of the appeal to be lodged against the strike ballot and this time period is set for forfeiture (Çifter, 1997: 92). A final decision shall be taken by the court regarding appeals within three working days, and the decision shall be valid even if it is taken after three working days (Reisoğlu, 1975: 370). The decision of the court is final and no appeal may be lodged against the decision of the court.

It has been stated in CASL Act No. 275 that competent trade union and workers are authorised in terms of the result of the ballot and the employer has no right to appeal (Çolakoğlu, 1971: 327). However, it should be noted that the employers' union or the employer not belonging to any union have the right to appeal against the strike ballot on grounds that the ballot has not been duly taken, the ballot has been corrupted, the ballot does not comply with the period, form of writing and conditions regulated by the CASL Act or due to other reasons 
(Reisoğlu, 1975: 369; Erkul, 1974: 188). The parties may lodge an appeal against the strike ballot due to some other reasons like corruption of the ballot and voting of those who have no right to participate in the ballot (Erkul, 1991: 206).

\subsubsection{Cancellation of a Strike Ballot}

There is no arrangement in CASL Act No. 2822 concerning how to act if the strike ballot is cancelled with court order. It has been stated that cancellation of the strike ballot as a result of appeals in the period of CASL Act No. 275 shall not necessarily mean that a new ballot may not be taken and it has also been stated that a new strike ballot is required whatever the reasons for a cancellation are (Reisoğlu, 1975: 371; Çolakoğlu, 1971: 328). However, it will be appropriate to investigate the reasons for cancellation. Request for a new strike ballot shall not be possible if the ballot is cancelled when it is revealed that the ballot is taken despite failure of attaining the required majority or termination of time limit set for forfeiture (Berksun and Eşmelioğlu, 1989: 548). However, it will be appropriate to take a new strike ballot due to reasons of irregularity during the course of ballot which may possibly affect the result (10). If cancellation of the strike ballot gives way to a new ballot to be taken, then a new ballot should be taken without need to a new request (Narmanlıoğlu, 2001: 633). If the trade union calls a strike without taking a second strike ballot when a new ballot should be taken upon the cancellation of the strike ballot by the court, that strike shall be considered unlawful (Tunçomağ, 1988: 502) (11).

\section{CONCLUSION}

Strike is a method resorted by trade union in case of collective labour disputes. In an aim to prevent union officers from taking strike decisions against the will of majority, it is regulated by laws to take strike ballots before taking the decision to strike. It is also observed that unions resort to strike ballot by including provision into their regulations when there is no related arrangement in laws in an effort to be more powerful before the employers during the course of strike, to initiate the strike with the support of their members and to make employers accept their requests.

Arrangements in Turkish labour law concerning strike ballot are not statutory. There should be an announced strike decision and a request for a ballot for a strike ballot to be taken. However, a strike shall not be considered unlawful if the strike is called without a request for taking a strike ballot. 
According to Turkish labour law, workers voluntarily decide whether to take part in a strike. The employer is also free in terms of whether to employ those workers not participating in the strike or not. Workers should quit job in case of a lock-out decision even if they do not participate in the strike and want to keep on working in the establishment. Those workers who want to work in the establishment by not participating in the strike may not benefit from the collective labour agreement to be concluded afterwards. As a strike to be called in the establishment shall affect all workers, the arrangement requiring the request of a specific ratio of workers employed in that establishment, whether union members or not, is an appropriate arrangement. With the application of a strike ballot the workers shall not be confronted with a strike against their will and the trade union shall not feel completely free in terms of calling a strike. However, it will be appropriate to include an arrangement in Turkish labour law stating that a strike ballot should be taken only among union members in the process of strike decision as applied in some countries. A strike ballot to be taken among union members before a strike decision is taken shall strengthen the position of the union before the employer. Although there is no arrangement in CASL Act No. 2822 preventing the trade union from including a provision in its regulation stating that a strike ballot shall be taken among its members before a strike decision is taken, this is not a common application.

The arrangement concerning the alternatives to be resorted in case of a decision against strike is taken as a result of the strike ballot taken in the establishment has removed the silence of law experienced on that particular matter in the past. However, the trade union may sign a collective labour agreement not having good conditions just for the sake of keeping its competence. Applying to the High Court of Arbitration results in an agreement signed against the free will of both parties. It is also observed that the trade union resorts to strike ballot in order to let the High Court of Arbitration handle the dispute and force the High Court of Arbitration to draft a collective labour agreement which the union itself is unable to conclude. Therefore, it will be appropriate to make an arrangement regulating the immediate forfeiture of competence after taking the strike ballot.

There is no arrangement in CASL Act No. 2822 concerning the effect of a decision taken against calling a strike in the establishment as a result of a strike ballot on the lock-out decision in Turkish labour law. However, it will be appropriate to make an arrangement stating that a lock-out decision shall be removed when a decision is taken against 
calling a strike in the establishment as a result of a strike ballot. It will also be very appropriate to make an arrangement in CASL Act No. 2822 stating how to act in case of cancellation of the strike ballot by the court upon an appeal against the ballot and whether another ballot may be taken without a new request depending on the reasons for cancellation.

In conclusion, the application of strike ballot may be improved by means of making some amendments in CASL Act No. 2822 concerning strike ballot. Although malicious use of the arrangement concerning strike ballot by the parties is encountered, we may also state that it is a democratic application providing opportunities to workers for expressing their opinions against a strike decision taken by the trade union contrary to the will of the majority of workers.

\section{Endnotes}

(1) According to the Article,

Workers have the right to strike and conclude collective labour agreements with their employers in an effort to safeguard and improve their financial and social conditions.

The exercise of the right to strike, its exceptions and employers' rights shall be regulated by law.

1961 Constitution Article 47/I, II.

(2) According to the Article,

Workers have the right to strike if a dispute arises in the course of collective labour agreement. The procedures and conditions governing the exercise of this right and the employer's recourse to a lock-out, the scope of both actions, and the exceptions to which they are subject shall be regulated by law.

1982 Constitution Article 54/l.

(3) According to the Article,

For the purposes of this Act, for an establishment agreement, the competent authority shall be the regional directorate of the Ministry of Labour and Social Security where the establishment is registered; for an enterprise agreement, it shall be the regional directorate of the Ministry of Labour and Social Security where the headquarters of the enterprise is registered, and for an agreement covering several establishments under the jurisdiction of more than one regional directorate, it shall be the Ministry of Labour and Social Security. 
CASL Act Article 18.

(4) According to the Article,

At an enterprise belonging to a legal or natural person or to a public organisation or institution that has more than one establishment in the same branch of activity, only one collective labour agreement may be concluded. Such an agreement shall be referred to as an enterprise collective labour agreement within the meaning of this Act.

CASL Act Article 3/II.

(5) According to the Article,

A strike ballot is taken in an establishment if one third of workers employed in that establishment request a strike ballot in writing within six working days as of the date of the announcement mentioned in paragraph 3 of article 23 .

The strike may not be called in that establishment if absolute majority of workers decide not to go on a strike as a result of the strike ballot.

A strike ballot shall be taken within six working days as of the date of request on such date and time outside working hours specified by the highest civil authority under his supervision or that of an official designated by him. Appeals against the ballot shall be lodged with a court of law having jurisdiction in labour matters within three working days as of the date of ballot. Final decisions to these appeals shall be taken within three working days.

The result of the strike ballot shall be recorded in a report, to be prepared in four copies. One copy shall be transmitted to the employer, another to the trade union that decided to call the strike and a third copy to the Regional Directorate of Labour. A fourth copy shall be retained by the highest civil authority in the locality.

CASL Act No. 275 Article 22.

(6) The request of one third of workers employed in an establishment whether union members or not is required for a strike ballot to be taken as per the decision of the Supreme Court adopted when CASL Act No. 275 was in effect. Y.9. HD. 13.10.1975, 28864/46110; İHU, TSGLK. 22 (No.2).

(7) According to the Article,

Any person holding a position as the employer's representative in an establishment and acting as a party to a collective labour agreement or 
during collective bargaining as a representative shall be deemed to be an employer for the purposes of this Act.

Article 62/II.

(8) It was stated in a decision of the Supreme Court that the form of writing for a request would be signed petitions of workers indicating their names and surnames which was adopted when CASL Act No. 275 was in effect. Y. 9. HD. 13.10.1975, 28864/46110; IHU, TSGLK. 22 (No.2).

(9) According to the Article,

Appeals to declare the agreement null and void shall be lodged with the court having jurisdiction in labour matters at the locality of the regional directorate where the establishment is registered. Where the collective labour agreement covers establishments under the jurisdiction of more than one regional directorate of the Ministry of Labour and Social Security, the appeal shall be lodged with the labour court in Ankara.

The judge, upon request and if he deems it necessary, may suspend the commencement of the collective labour agreement until a decision is taken.

Article 16/III, IV.

(10) The ballot was cancelled by the court when some workers who were no longer employed voted during the lawful strike ballot. However, the decision of the court concerning that the strike may be called without any obstruction was overruled by the Supreme Court on grounds that the strike may not be called without taking a new ballot. YHGK. 03.04.1968, 9-846/226; Berksun and Eşmelioğlu, 1989: 548.

According to the Article,

Any person resorting to fraud, threats or force with the object of influencing the result of a strike ballot shall be liable to a term of imprisonment of not less than three months and not more than one year.

CASL Act Article 76.

(11) The Supreme Court considered it unlawful to call a strike without taking a second strike ballot when the result of a strike ballot taken within the time limit was cancelled by court due to some reasons and a request was made for a second ballot during the period when CASL Act 
No. 275 was in effect. Y. 9. HD., 03.04.1968, 1967-9-846/226; Orhaner and Orhaner, 1969: 676-677.

\section{REFERENCES}

Berksun and Eşmelioğlu (1989), Açıklamalı Gerekçeli-lçtihatı Toplu Iş Sözleşmesi Grev ve Lokavt Kanunu. Ankara: Seçkin.

Çelik, Nuri (2004), İs Hukuku Dersleri, İstanbul: Beta.

Çifter, Algun (1997), Grev Oylaması, Prof. Dr. KENAN TUNÇOMAĞ'a Armağan, İstanbul: İstanbul University, p. 76-100.

Çolakoğlu, H. Servet (1971), Toplu İş Sözleşmesi Grev ve Lokavt Hukuku, Ankara: Ayyıldız Matbaaası.

Ekonomi, Münir, IHU, TSGLK. 22 (No.1).

Erkul, Ihsan (1991), Türk Iş Hukuku Dersleri 2822 Sayılı Toplu Iş Sözleşmesi Grev ve Lokavt Kanunu Vol.3, Eskişehir: Anadolu University.

Erkul, Ihsan (1974), Türk İş Hukuku Dersleri 275 Sayılı Toplu İş Sözleşmesi, Grev ve Lokavt Kanunu ve Uygulaması Vol.3, Eskişehir: Anadolu University.

Güven and Aydın (2002), İş Hukuku, Eskişehir: Anadolu University.

Kocaoğlu, Mehmet (1986), 2822 sayılı Kanundaki Yeni Düzenlemelerle Grev Oylaması, Tühis, 10:2, p.3-27.

Kutal, Metin (1975), Grev Oylaması'nın Hukuki Esasları ve Doğurduğu Sorunlar, Iktisat ve Maliye, 22:8, p.333-337.

Narmanlıoğlu, Ünal (2001), İş Hukuku II Toplu İş Ilişsileri, İmir: Dokuz Eylül University.

Narmanlıoğlu, Ünal (1990), Grev, Ankara: Ankara University.

Oğuzman, Kemal (1987), Hukuki Yönden İşçi-Işveren Iliş̧kileri Vol.1, İstanbul: Yön Ajans.

Oğuzman, M. Kemal (1975), Hukuki Yönden İşçi-Işveren Ilişkileri Temel Bilgiler Toplu İlişkiler Vol.1, İstanbul: İstanbul University.

Orhaner and Orhaner (1969), Türk Iş Hukuku Yargıtay Emsal Kararları, Ankara: Sevinç Matbaası.

Reisoğlu Seza (1975), Toplu İş Sözleşmesi Grev ve Lokavt Kanunu, Ankara: Ayyıldız Matbaası.

Sendikalar ve Grev, Lokavt Hakları (1964), Ankara: Türk-Iş. 
Sur, Melda (1987), Grev Kavramı, Izmir: Dokuz Eylül University.

Tunçomağ, Kenan (1988), İs Hukukunun Esasları, İstanbul: Beta.

Ünal, Ayşe (1993), Çeşitli Ülkelerde ve Türkiye'de Grev Oylaması, Bursa. 
Figure 1

\section{Determination of Competence in Collective Labour Agreements}

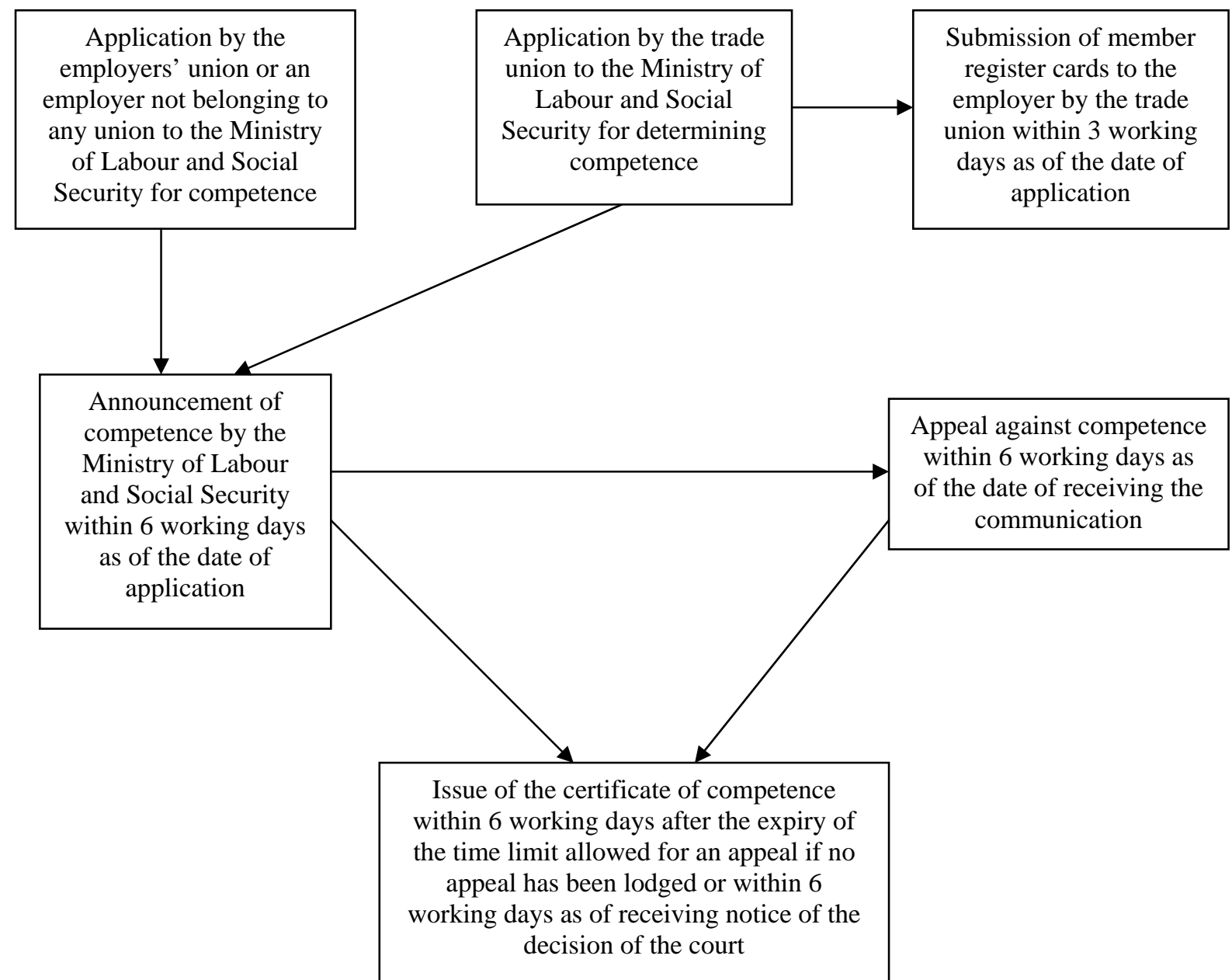

Figure 2

\section{Invitation to Collective Bargaining}

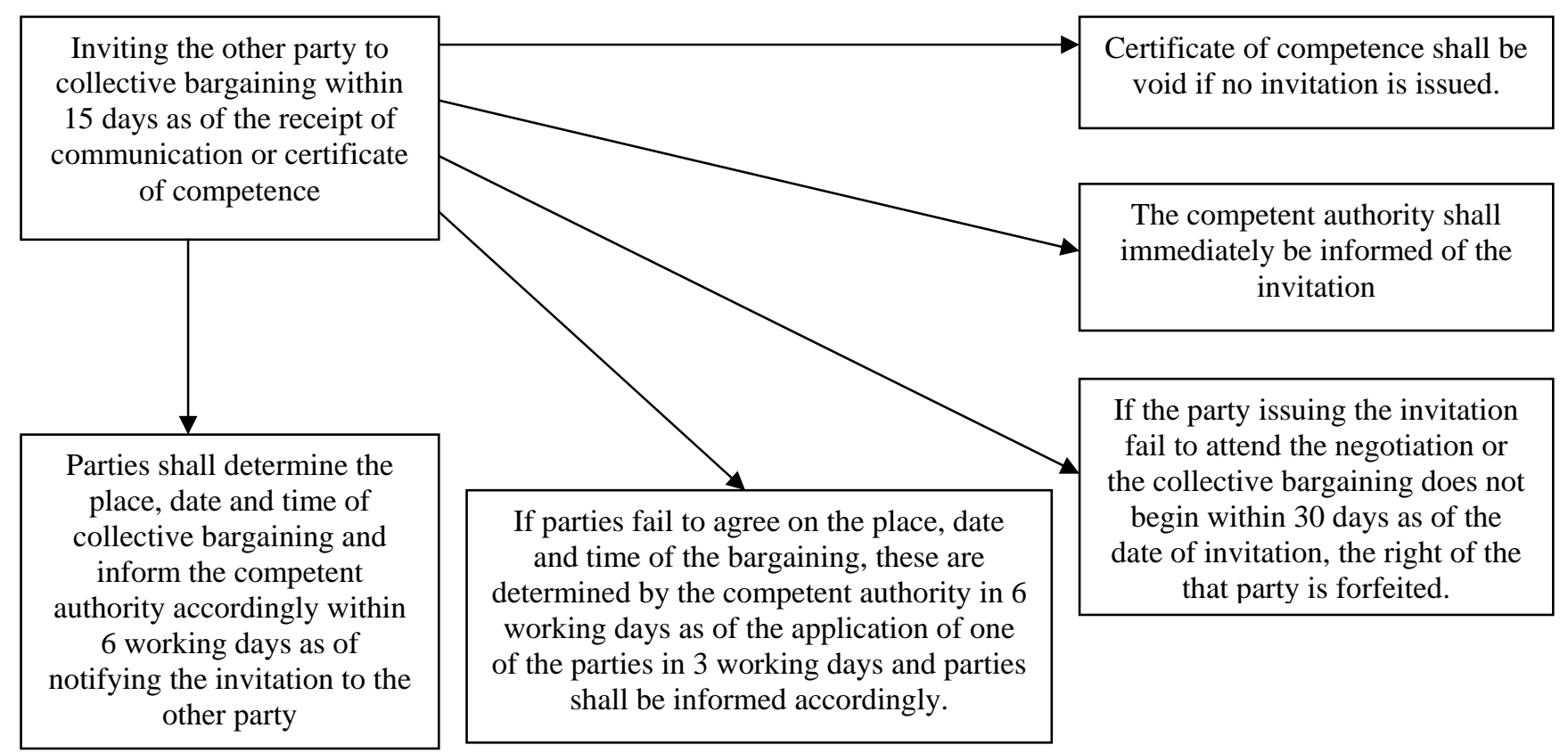


Figure 3

\section{Notification of a Dispute}

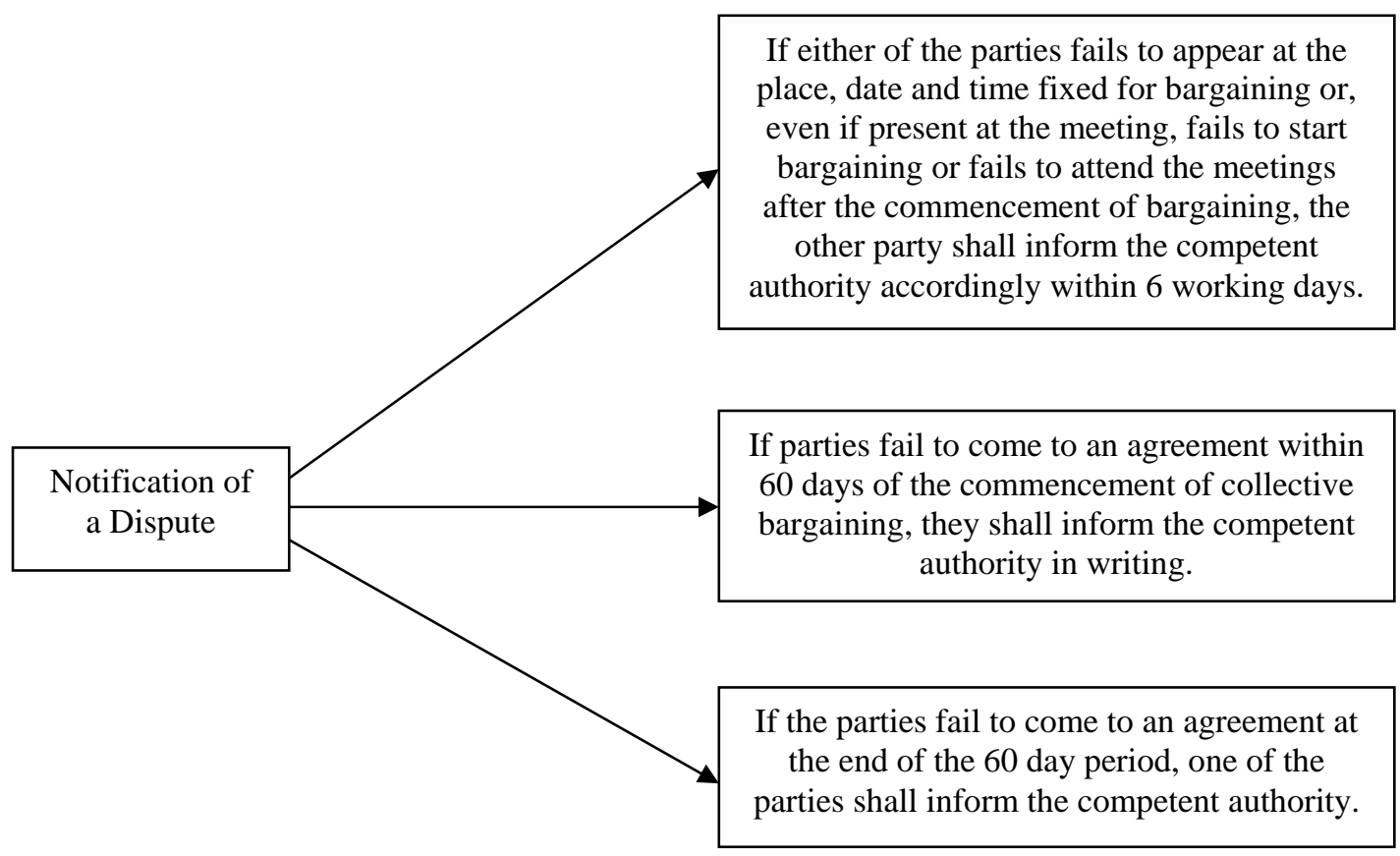

Figure 4

\section{Announcement of Strike}

The related trade union may decide to call a strike within 6 working days as of the $6^{\text {th }}$ day of the notification of parties of the dispute report prepared by the mediator

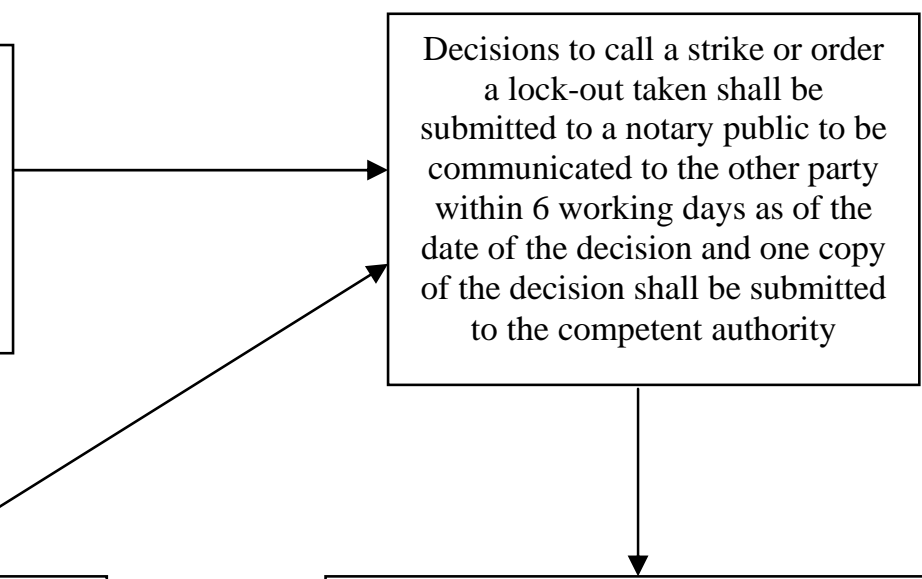

Employers' union or employer not belonging to a employers' union may decide to order a lock-out within 6 working days as of being notified of strike decision by the trade union.

Decisions to call a strike or order a lockout may be executed within 60 days as of the date of notification to the other party and within 6 working days as of the date of notification through the notary. 